\title{
ANALYSIS OF TECHNICAL ASSUMPTIONS OF SELECTION OF ELEMENTS OF A LANDFILL SITE ON THE MUNICIPAL AREA
}

\author{
Grzegorz Przydatek, Aleksander Pietrzak \\ Technical Institute, State Higher Vocational School in Nowy Sącz \\ *Corresponding author: e-mail: g.przydatek@gmail.com
}

\begin{tabular}{|c|c|}
\hline ARTICLE INFO & ABSTRACT \\
\hline $\begin{array}{l}\text { Article history: } \\
\text { Received: November } 2015 \\
\text { Received in the revised form: } \\
\text { February } 2016 \\
\text { Accepted: May } 2016\end{array}$ & \multirow{2}{*}{$\begin{array}{l}\text { The paper presents environmental conditions for the selected location } \\
\text { of a landfill site on the area of Stary Sacz designated for deposing } \\
\text { neutral waste from the installation for secondary segregation of waste. } \\
\text { Based on the productivity of the selected municipal waste parameters } \\
\text { of accumulation indicators were determined strictly correlated with } \\
\text { the amount of waste predicted for disposal. Components of the facility } \\
\text { were selected including the requirements of the resolution as of 30th } \\
\text { April } 2013 \text { on landfill sites (Journal of Laws } 2013 \text { item 523) for } \\
\text { application of solutions for protection of water, soil and atmospheric } \\
\text { air environment in its surroundings against the negative impact of } \\
\text { waste. The paper also refers to the final stage related to closing of } \\
\text { a landfill with the assumed plan of its reclamation. The article was } \\
\text { summed up with conclusions indicating the limited possibility of } \\
\text { location of such a facility on the selected area on account of its loca- } \\
\text { tion close to Poprad River and on the area of the Main Reservoir of } \\
\text { Underground Water. The objective of the paper was to make an } \\
\text { attempt to choose components of the installation for neutralization of } \\
\text { waste in Stary Sącz taking into account the local environmental condi- } \\
\text { tions. }\end{array}$} \\
\hline $\begin{array}{l}\text { Key words: } \\
\text { municipal waste, } \\
\text { landfill site, } \\
\text { depositing }\end{array}$ & \\
\hline
\end{tabular}

\section{Introduction}

Disposing waste on landfills is one of the simplest methods of their neutralization. Landfill sites are engineering facilities the existence of which is strictly related to human living and collection of various waste and decomposition time on their area (Przydatek, 2012a). According to the Main Statistical Office (www.stat.gov.pl) in 2013 there were 431 open landfill sites in Poland, where municipal waste were neutralized. These landfills played a role of regional or replacing installations.

Arranging waste landfills includes their suitable location with regard to environmental conditions, their equipment, exploitation and control of the environment pursuant to the guidelines of the Minister of Environment of 30th April 2013 on landfill sites (Journal of Laws 2013 item 523, www.sejm.gov.pl). Closing and reclamation which makes it possible to return the initial values to the degraded area is also crucial. Despite new techniques of reclamation and neutralization, neutralization of waste through disposing on landfills is treated as a final solution pursuant to the hierarchy of proceeding. 
The paper attempts to select components of an installation for waste treatment in the town of Stary Sącz taking into account local environmental conditions.

\section{Characteristic of environmental conditions of the area of the selected municipality}

The urban and rural municipality of Stary Sącz is located in the south-west part of Nowy Sacz district in Małopolskie Voivodeship. It takes the area of $102.4 \mathrm{~km}^{2}$, which constitutes approximately $6.61 \%$ of the area of Nowy Sącz district. Stary Sącz has a specific microclimate. The land shape causes local temperature dropping particularly in the winter season and the increase of air moisture. The average annual temperature fluctuates within $6-8^{\circ} \mathrm{C}$ and the annual sum of precipitation is from $750 \mathrm{~mm}$ to $800 \mathrm{~mm}$. July is the rainiest month and the lowest amount of precipitation is in winter. Two types of soils can be distinguished here: shallow loamy soils (skeleton soil) and medium deep loamy soils which are most often classified as IV and V soil quality class. The town of Stary Sącz is located on the route from Poprad estuary to Dunajec. Within the municipality, there is a typical for Polish Carpathian Mountains morphological trigeminality (i.e. a flat valley, the zone of foothills and the typical mountainous area). The municipality focuses precious elements of natural environment within its borders. In its south and south-east part there is a piece of Poprad Landscape Park (Program, 2004). The entire area of the city and municipality is within The South Małopolska Area of Protected Landscape.

\section{Conditions for location of a landfill}

The increase of requirements in the environment protection caused a considerable reduction and narrowing of areas which may be used for location of landfills. The resolution of the Minister of Environment of 30th April 2013 on landfill sites (Journal of Laws of 2013 item 523), sets forth the requirements concerning, inter alia, location, construction and maintaining landfills of waste other than dangerous and neutral. They cannot be located particularly on the area of protected reservoirs of underground water, in the zones of landslides and sinkholes as well as on the area whose slope is more than $10^{\circ}$, areas of protection zones of national parks and nature reserves and on the areas of shelterwoods. This regulation indicates that the distance of a landfill from buildings should be determined pursuant to the report on the influence of the undertaking on the environment, which should be subjected to social consulting as a part of assessment of the environmental impact.

Research concerning determination of location of landfills has a two-phase nature. The first phase consists in the selection of land, where a landfill will be located and the second phase classifies geological and hydrological conditions of the ground (Wysokiński, 2009). Hydrological conditions on the selected area are too good, which may result from accumulation of the Main Reservoir of Underground Water no. 439 Magura (Gorce Mountains). (Program, 2004; Program, 2012). On the other hand, depth of accumulation of underground water on the analysed area at the average level of 3.40 metres below the ground level is favourable and slate formations, are not favourable for migration of underground water. Downflow of underground water heads towards Poprad river (Dokumentacja..., 1996).

A natural geological barrier which seals the ground and side walls at the determined minimal thickness and the value of the filtration indicator of the geological barrier is a basis for location of the installation for neutralization of waste (Jamróz, 2012). 
Analysis of technical assumptions...

A geological base consists of the opening of Carpathian flysch of Magura nappe which include the layers of sandstone and slate with marl (Dokumentacja..., 1995).

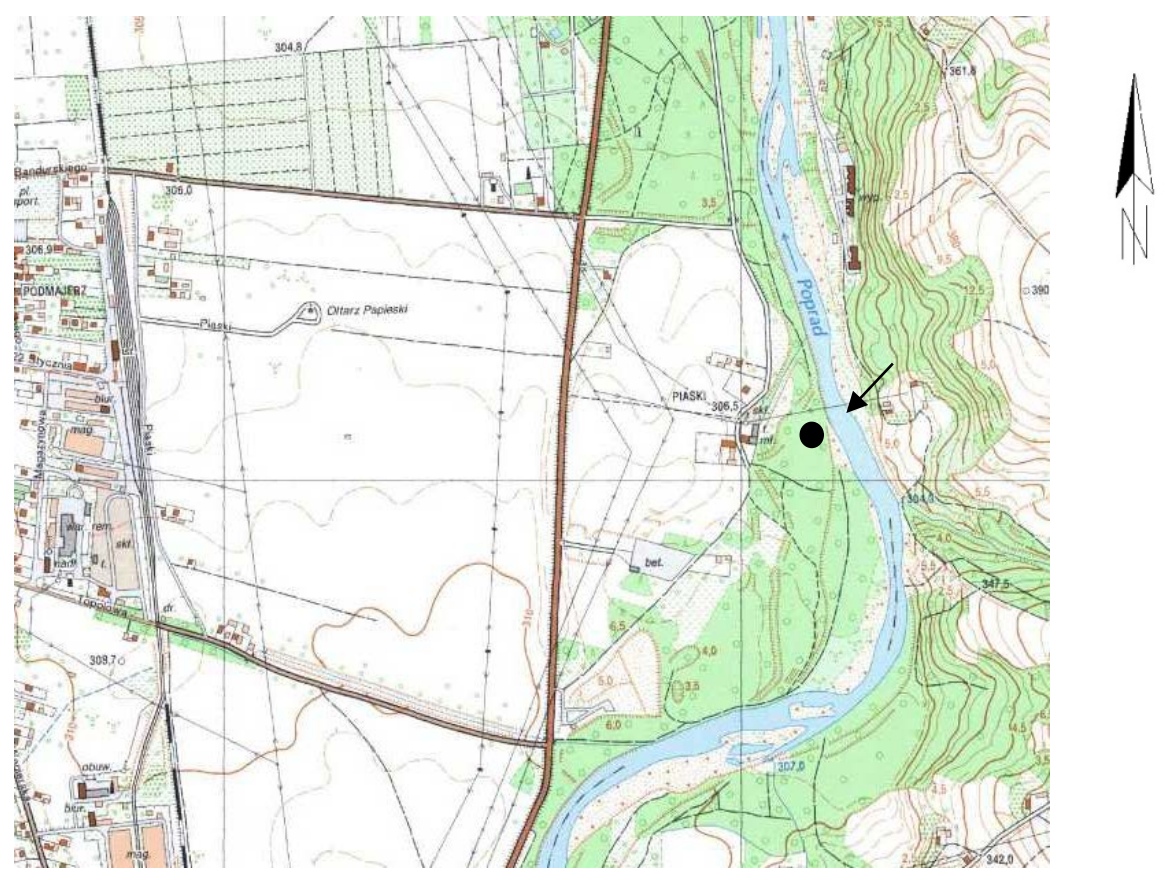

Figure 1. The proposed location of the municipal landfill site in Stary Sacz municipality (www.mapy.geoportal.gov.pl)

The location suggested in the eastern part of the city has a mild slope of the area at the average ordinate of $310 \mathrm{~m}$ above the ground level, which is less available on the mountainous area. This location is ca. $0.6 \mathrm{~km}$ from Poprad River, which flows towards the east, while the closest residential buildings are $1 \mathrm{~km}$ to the west (fig. 1). The indicated location as a single suggestion for the concept of a neutral waste landfill from the set up installation for secondary segregation of waste was built based on the consultation with the municipal entity which deals with waste management on the area of the town and municipality of Stary Sącz.

\section{Analysis of waste productivity}

The amount of $176 \mathrm{Mg}$ of municipal waste after the initial segregation process in the set up sorting plant on the area of the town of Stary Sacz was accepted for conceptual assumptions of a landfill based on the morphological composition and statistical data (GUS [Main Statistical Office], www.stat.gov.pl, www.malopolskie.pl). In the general morphological composition of waste for Stary Sacz, the forecasted participation of waste designed for 
disposal presents the highest participation of fraction below $10 \mathrm{~mm}$ (7\%), and the lowest of mineral waste (3\%). The remaining wastes were not included on account of raw material properties (fig. 2).

Determination of the value of waste accumulation indicators - the volumetric and weight one is a significant issue for undertakings related to construction of landfill sites, including technological solutions.

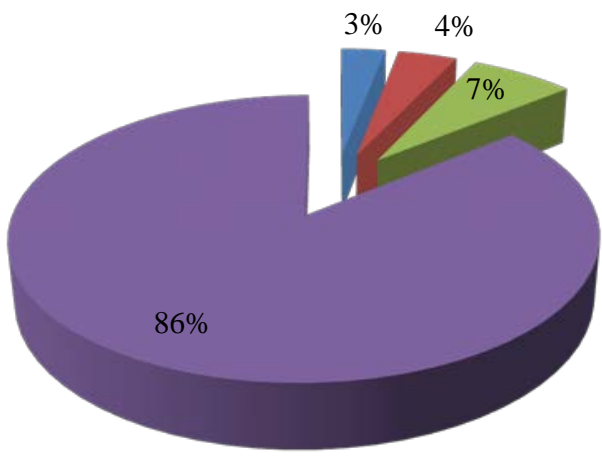

mineral waste $\llbracket$ other waste types $\llbracket$ waste fraction below $10 \mathrm{~mm}$ ॠ other

Figure 2. Morphological composition of municipal waste of Stary Sacz municipality (GUS, www.stat.gov.pl, www.malopolskie.pl

The indicator of weight accumulation was calculated based on the formula (Wolski, 2009):

$$
b_{m}=\frac{m}{M * d}\left(\mathrm{~kg} \cdot \mathrm{M}^{-1} \cdot \mathrm{db}^{-1}\right)\left(\mathrm{kg} \cdot \mathrm{M}^{-1} \cdot \operatorname{rok}^{-1}\right)
$$

where:

$\mathrm{m} \quad$ - mass of disposed waste (remaining after initial segregation),

M - number of population,

d - number of days of collecting waste (365 days).

Volumetric accumulation indicator $\left(\mathrm{bo}_{\mathrm{bj}}\right.$ ) was calculated based on the following formula:

where:

$$
b_{o b j}=\frac{v}{M * d}\left(\mathrm{dm}^{3} \cdot \mathrm{M}^{-1} \cdot \mathrm{db}^{-1}\right)\left(\mathrm{dm}^{3} \cdot \mathrm{M}^{-1} \cdot \mathrm{rok}^{-1}\right)
$$

$\mathrm{v}_{\mathrm{i}}$ - the accepted volume of collected waste (remaining after initial segregation),

$\mathrm{M}$ - number of population,

d $\quad$ - number of days of collecting waste (365 days).

Density (weight of volume) of waste was calculated based on the formula:

$$
G=\frac{b_{m}}{b_{o b j}} \quad\left(\mathrm{~kg} \cdot \mathrm{m}^{-3}\right)
$$


Analysis of technical assumptions...

Table 1.

The input data to the calculations of the accumulation indicators (CSO 2013; Rosik-Dulewska 2011)

\begin{tabular}{lcccc}
\hline $\begin{array}{l}\text { City and } \\
\begin{array}{l}\text { Municipality } \\
\text { of Stary Sącz }\end{array}\end{array}$ & $\begin{array}{c}\text { Mass of collected } \\
\text { waste } \\
\left(\mathrm{kg} \cdot \mathrm{year}^{-1}\right)\end{array}$ & $\begin{array}{c}\text { Number of } \\
\text { citizens }\end{array}$ & $\begin{array}{c}\text { Number of days when } \\
\text { waste was collected } \\
\left(\text { days } \cdot \mathrm{year}^{-1}\right)\end{array}$ & $\begin{array}{c}\text { Volume of waste } \\
\mathrm{vi}\left(\mathrm{dm}^{3} \cdot \mathrm{year}^{-1}\right)\end{array}$ \\
\cline { 2 - 5 } & 176000 & 23,390 & 365 & 3372838 \\
\hline
\end{tabular}

Table 2.

Waste accumulation indicators

\begin{tabular}{lccccc}
\hline $\begin{array}{l}\text { City and } \\
\text { Municipality } \\
\text { of Stary }\end{array}$ & \multicolumn{2}{c}{$\begin{array}{l}\text { Indicators of mass } \\
\text { waste accumulation }\end{array}$} & \multicolumn{2}{c}{$\begin{array}{c}\text { Indicators of volumetric } \\
\text { waste accumulation }\end{array}$} & $\begin{array}{l}\text { Waste thick- } \\
\text { ness (weigtht } \\
\text { Sącz }\end{array}$ \\
\cline { 2 - 6 } & $\mathrm{b}_{\mathrm{m}}\left(\mathrm{kg} \cdot \mathrm{M}^{-1} \cdot \mathrm{db}^{-1}\right)$ & $\mathrm{b}_{\mathrm{m}}\left(\mathrm{kg} \cdot \mathrm{M}^{-1} \cdot \mathrm{rok}^{-1}\right)$ & $\mathrm{b}_{\mathrm{obj}}\left(\mathrm{dm}^{3} \cdot \mathrm{M}^{-1} \cdot \mathrm{db}^{-1}\right)$ & $\mathrm{b}_{\mathrm{obj}}\left(\mathrm{m}^{3} \cdot \mathrm{M}^{-1} \cdot \mathrm{rok}^{-1}\right)$ & $\mathrm{G}\left(\mathrm{kg} \cdot \mathrm{m}^{-3}\right)$ \\
\cline { 2 - 6 } & 0.02 & 7.52 & 0.40 & 0.14 & 52.18 \\
\hline
\end{tabular}

The showed indicators of weight and volume accumulation of waste reported on the area of the city and municipality are lower than the values achieved in the national conditions, which in case of the first indicators are within 49.67 to $84.46 \mathrm{~kg} \cdot \mathrm{M}^{-1} \cdot \mathrm{year}^{-1}$, and the second from 0.91 to $3.13 \mathrm{~m}^{3} \cdot \mathrm{M}^{-1} \cdot \mathrm{year}^{-1}$ (Kaczor and Bergel, 2006; Gąska and Generowicz, 2014). On the other hand, the obtained low value of the bulk density acc. to Rosik - Dulewska [2011] is characteristic for urban centres. Based on this, one may recognize that parameters of the landfill and the period of exploitation should be strictly related to the size of the stream of disposed waste.

\section{Construction of a landfill}

\section{Sealing}

To exclude a threat from a negative impact of waste on the environment it is recommended to use shutters which insulate the ground and side walls with filtration indicators showing a considerable reduction of effluents migration. It should be emphasised that synthetic insulation, designed in a way that takes into account a chemical composition of waste and geotechnical conditions of disposal, complements a natural and artificial geological barrier. To dispose neutral waste thickness of a natural geological barrier should be not less than $1 \mathrm{~m}$ and the filtration indicator $\mathrm{k} \leq 1.0 \times 10^{-7} \mathrm{~m} \cdot \mathrm{s}^{-1}$. On the analysed area the filtration indicator is $\mathrm{k} \leq 1.0 \times 10^{-5} \mathrm{~m}^{-1} \mathrm{~s}^{-1}$ and is lower than the suspected one, which results from sandy loam deposits with layers of loamy sand with the mixture of medium sand (Dokumentacja..., 1995). Thus, the use of an insulating plastic shutter is expected. In case of insulating the landfill a draining system placed on the insulation layer, whose task is to catch and dispose sewage, is used (Jamróz, 2012).

Catching and disposal of leachate

A waste bed can absorb infiltrating water to the state of full saturation. Leachate water which is thus formed on landfills should be collected in a reservoir or directly supplied through a sewage system to the technologically relevant sewage treatment plant. 
Water balance of the area where waste from a specific landfill is disposed may be expressed as follows (Machajski and Olearczyk, 2008):

for top layers of a landfill in the form of the following expression

$$
H=P+S_{p}-D_{p}+\frac{d W_{p}}{d t}+f_{o}\left(\mathrm{~mm} \cdot \mathrm{m}^{-2} \cdot \mathrm{d}^{-1}\right)
$$

where:

$\mathrm{H}$ - amount of precipitation, mean annual from a multi-annual term for a given area, $(\mathrm{mm})$

$\mathrm{P} \quad$ - vapouring amount, mean annual from a multi-annual term for a given area; $\mathrm{mm}$

$S_{p} \quad$ - down flow on the surface of the top layer of a landfill,

$D_{p} \quad-$ size of the surface inflow (from the adjacent area),

$\mathrm{W}_{\mathrm{p}}$ - water participation in the layer which covers a landfill which results from its sorption capacity (relative moisture $\mathrm{x}$ height of the waste layer), $\left(\mathrm{mm} \cdot \mathrm{m}^{-2}\right)$

t $\quad$ - time; (day)

$\mathrm{f}_{\mathrm{o}} \quad$ - outflow of leaks from the layer which covers a landfill inside the deposition chamber - waste bed, (mm)

for the bottom layer of waste deposited on a landfill in the form of the following expression:

$$
H=\frac{d W_{o}}{d t}+W G_{d}-W G_{p}\left(\mathrm{~mm} \cdot \mathrm{m}^{-2} \cdot \mathrm{d}^{-1}\right)
$$

where:

$f_{0} \quad-$ outflow of leachate to the ground,

$W_{\mathrm{d}}-$ inflow to ground water,

$W_{\mathrm{p}}$ - uptake of ground water,

$\mathrm{W}_{\mathrm{o}} \quad$ - water content in the waste bed.

Dehydration of a landfill

According to the resolution of the Minister of Environment of 30th April 2013 on landfills (Journal of Laws of 2013 item 523) their equipment with the drainage system of leachate water is required. Its reliable functionality should include exploitation and postexploitation period of 30 years after the landfill is closed. The drainage system should include a drainage layer of gravel and sand material (whose filtration indicator $\mathrm{k}$ exceeds $1 \times 10^{-4} \mathrm{~m} \cdot \mathrm{s}^{-1}$ ). The main drainage system which disposes leachate to the main collector should be placed in the drainage layer. Landfill slopes should be equipped with the drainage system which allows the outflow of leachate to the main drainage system.

Around the neutral waste landfill there should be an outside system of drainage ditches which allows underground and ground water inflow to the landfill if the research indicates so.

Degassing a landfill

Degassing a landfill is not planned since it will be a neutral waste landfill.

Separating quarters

Pursuant to the resolution of the Minister of Environment of 30th April 2013 on landfills, quarters are separated. Their volume is determined in the construction project and they 
Analysis of technical assumptions...

are equipped and exploited in stages. Their significant role is a possibility to separately dispose waste on the indicated areas in various time perspective.

Insulation layer

To prepare an insulation layer, no waste of the same type as the waste disposed on a landfill is used. Participation of the insulation layer in relation to the layer of disposed waste should not exceed 15\%. The insulation layer should consist of 2 types of a layer: a daily layer $(0.15 \mathrm{~m})$ and interlayer $(0.3 \mathrm{~m})$. Waste should be covered with these layers each day. The layers should be periodically controlled and completed if needed. They may consists of concrete and construction rubble waste from demolition and renovation, brick rubble, mixed brick rubble waste, ceramic materials waste, soil and land. Endurance of the daily layer should be 7 days and the interlayer one - one year (Wladarz, 2003; Jamróz, 2012).

Methods of construction of landfills

The most desirous is construction of organized landfills which have a special location including hydrological and geotechnical criteria which meet the technical and technological requirements of exploitation (fig. 3). On account of the local environmental conditions related to Poprad River which flows nearby and deposits of the Main Reservoir of Underground Water, a landfill should be on the surface, namely its should rise over the ground during gradual waste disposal.

The analysed landfill classified as organized as a modern facility should have a properly selected structure and in particular a horizontal plastic insulation and a correct usage which enables minimization of a negative impact of waste disposal on the environment both during the exploitation and thereafter (Przydatek, 2012b; Rosik-Dulewska, 2011; Żygadło 2001, 2002)

\section{Exploitation of a landfill}

Exploitation of a landfill should meet the following guidelines (Rosik-Dulewska, 2011):

- reduction of the disposed waste exposed to atmospheric conditions,

- steps against blowing out waste from a landfill,

- collection of leachate and subjecting them to cleaning in a degree that allows their acceptance to the sewage treatment plant,

- geotechnical stability of disposed waste.

A correct exploitation of a landfill should be also related to a proper use of the facility capacity and with minimization of the working surface. 


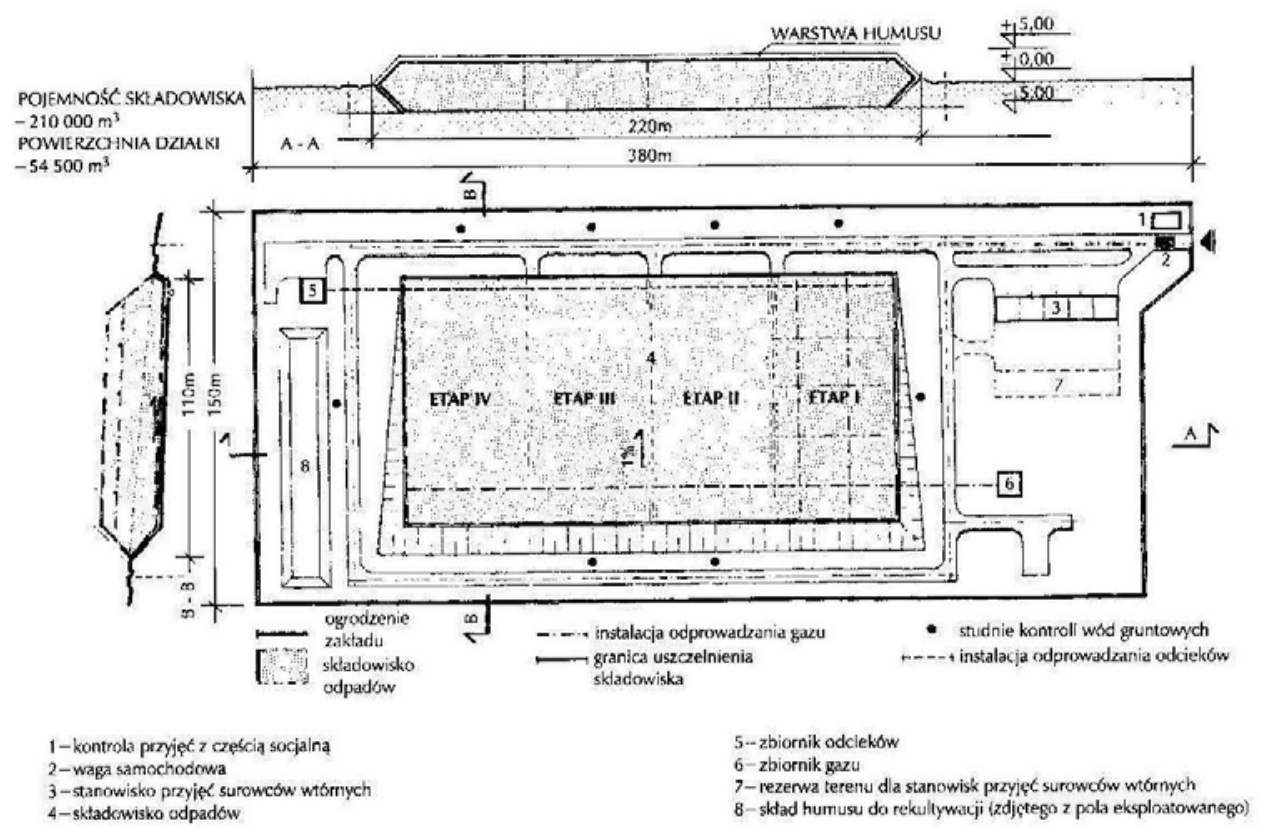

Figure 3 . Plan of correct arrangement of a landfill (Rosik-Dulewska, 2011)

\section{Technical and social facilities of a landfill site}

Cubature facilities and technical devices of the analysed landfill should include:

- an administrative and social facility with showers, toilet and changing rooms for the employees of a landfill,

- car weight - for measurement of waste accepted to a landfill supplied with cars,

- a technical facility - to be used as a warehouse for machines operating on the site, garage, repair workshop, disinfectants and tools storage,

- fuel storage - for collection of fuels for the machines working on the site,

- car washer - for washing and disinfection of wheels of vehicles that leave the facility,

- connection to the electric power supply,

- a storehouse for insulation material - for collection of material other than waste or wastes for the insulation layer,

- a technical road - with a hardened surface enabling free move of vehicles with waste and after unloading,

- fencing - disabling the access of unauthorized persons and illegal disposal of waste,

- lighting - street lights at the entrance and technical road for safe use of the facility,

- piezometers - for measurement of the level of underground water and collection of samples for quality tests, 
Analysis of technical assumptions...

- green space - composed of trees and bushes with the minimal width of $10 \mathrm{~m}$, which should surround the landfill area for minimization of nuisance related to its use including emission of odours and dust.

\section{Landfill control}

Before and after the entire period of exploitation of the landfill and after its closing the condition of the natural environment should be monitored within its area. The role of the monitoring is to evaluate the impact of such a municipal facility on the environment. Pursuant to the resolution of the Minister of Environment of 30th April 2013 on landfills the monitoring includes 3 stages:

- Before exploitation consisting in:

- determination of mean meteorological data proper for location of a landfill,

- measurement and evaluation of compliance with the level of underground water in the observation windows predicted in the landfill construction plan,

- determination of the spots of collecting samples and indicators parameters for further monitoring tests separately for ground, leachate and underground water,

- determination of a geochemical background of ground and underground water,

- With exploitation which includes:

- tests on the amount of precipitation from the measurements carried out on the area of the landfill site,

- measurement of the level of underground water in observation windows,

- measurement of the size of ground water flow,

- control of settlement of the landfill surface based on the determined benchmarks,

- tests of the determined indicator parameters in ground leachate water, underground water and in the landfill gas,

- measurement of the landfill gas emission,

- With exploitation which includes:

- tests on the amount of precipitation from the measurements carried out on the area of the landfill site,

- measurement of the level of underground water in observation windows,

- measurement of the size of ground water flow,

- control of settlement of the landfill surface based on the determined benchmarks,

- tests of the determined indicator parameters in ground leachate water, underground water and in the landfill gas,

- measurement of the landfill gas emission,

\section{Closing and reclamation of landfills}

During the closing of a landfill or its part, reclamation work is carried out in a manner which protects the environment against harmful impact of waste on the ground and underground water and air, which integrates the area of waste environment with the surrounding environment and enables observation of the impact of a landfill on the environment. 
Waste brought in the final stage of exploitation may be used in order to suitably shape the block (www.ochronasrodowiska.eu). After exploitation of the landfill, scarp and the surface of the crown of the landfill should be cleaned and secured against water and wind erosion through making a proper reclamation cover, the structure of which depends on the waste properties. A minimum thickness of the reclamation cover for the indicated waste landfill should enable formation and maintenance of the permanent plant cover.

Reclamation aims at returning the utility values to the degraded area. Rosik-Dulewska (2011) divides reclamation into two types:

- a technical one, which starts with construction and lasts until the end of exploitation of

a landfill and constitutes the last element of the facility exploitation,

- a biological one, which starts with shaping a scarp and terraces and lasts till a target user takes over the land.

It is suggested that reclamation should be related to forestry and production. This solution depends on many factors, in particular on environmental conditions of the surroundings. However, this trend is low effective. Thus, as a part of the production trend of land development after a landfill it is possible to form a deciduous tree plantation than the typically forest plants for phyto-melioration and recreational purposes, which is related to formation of the reclamation cover with a relevant thickness.

\section{Conclusion}

Based on the analysis of selection of landfill elements on the area of the selected municipality one may formulate the following conclusions:

- the suggested location in the eastern part of the city is distinguished by a mild declination of the land and an optimal level of underground water deposition which is not fully available in the mountains,

- the initial analysis of environmental conditions did not show any considerable obstacles for the location of a landfill except for the Protected Landscape Area of the South part of Małopolska Region,

- small distance from Poprad River is a possible threat in case of exceeding the emergency levels of water from the closest watercourse,

- in order to justify the suggested location of a landfill it is required to recognize the local geological and hydrological conditions on account of the Main Reservoir of Underground Water,

- indicators of waste accumulation on the area of the selected entity may constitute significant parameters for the structural solution of a landfill,

- the showed form of arrangement of a landfill should correspond to reduction of the negative impact of disposed waste on the environment in the stage of exploitation and after its closing,

- the final trend of reclamation should be adequate to the development of the surroundings of the landfill. 
Analysis of technical assumptions...

\section{References}

Dokumentacja geologiczno-hydrogeologiczna, (1995-1996). Stary Sącz,

Generowicz, A., Gąska, K. (2014). Research on waste generation indicators for 40 thousand inhabitants community. Archives of Waste Management. ISSN 1733-4381.

Jamróz, A. (2012). Prawidłowa budowa, eksploatacja i rekultywacja składowisk odpadów zgodnie z przepisami prawa polskiego. Czasopismo Techniczne, Zeszyt 4, Wyd. Politechnika Krakowska, Kraków, 87-100.

Kaczor, G., Bergel, T. (2006). Szacowana a rzeczywista ilość odpadów komunalnych zbieranych w gminach wiejskich. Infrastruktura i Ekologia Terenów Wiejskich. Nr 3/2/, 5-16.

Główny Urząd Statystyczny (2013). www.stat.gov.pl

Machajski, J., Olearczyk, D. (2008). Bilans wodny w obrębie składowiska odpadów komunalnych. Infrastruktura i Ekologia Terenów Wiejskich. Nr 7, 89-100.

Program Ochrony Środowiska dla Miasta i Gminy Stary Sącz na lata 2004-2011 wraz z Prognozą do roku 2015. (2004). Stary Sącz

Program Ochrony Środowiska dla Powiatu Nowosądeckiego na lata 2012-2015 z perspektywą do roku 2019. (2012). Nowy Sącz

Przydatek, G. (2012a). Jakość wód podziemnych w rejonie użytkowanego składowiska odpadów. Infrastruktura i Ekologia Terenów Wiejskich Nr 1/IV, 59-70.

Przydatek, G. (2012b). Ocena sprawności systemu odwodnienia eksploatowanego składowiska odpadów komunalnych. Infrastruktura i Ekologia Terenów Wiejskich Nr 2/III, 217-226.

Rosik-Dulewska, C. (2011). Podstawy gospodarki odpadami. PWN, Warszawa. ISBN 9788301163532

Rozporządzenie Ministra Środowiska z dnia 30 kwietnia 2013 r. w sprawie składowisk odpadów (Dz. U. z 2013 r. poz. 523).

Władarz, M. (2003). Gospodarka odpadami. Poradnik przedsiębiorcy. Warszawa. ISBN 83-8880264-X

Wolski, W. (2009). Projekt budowlany rekultywacji sktadowiska odpadów. Warszawa.

Wysokiński, L. (2009). Zasady budowy składowisk odpadów. Instytut Techniki Budowlanej, Warszawa

Żygadło, M. (pod red.). (2001). Strategia gospodarki odpadami komunalnymi. Wyd. PZITS, Poznań.

Źygadło M., (2002). Gospodarka odpadami komunalnymi. Wyd. Politechniki Świętokrzyskiej, Kielce, $1-300$

Rekultywacja. (on-line). 2015. Obtained from: www.ochronasrodowiska.eu/nowosci/rekultywacja-

skladowiska- odpadow-kto-kiedy-i-dlaczego-224834.html dostęp 17.04.2015 r.

www.geoportal.gov.pl dostęp 20.04.2015 r.

www.malopolskie.pl dostęp 18.06.2016 r. 
Grzegorz Przydatek, Aleksander Pietrzak

\section{ANALIZA ZALOŻEŃ TECHNICZNYCH DOBORU ELEMENTÓW SKLADOWISKA ODPADÓW KOMUNALNYCH NA TERENIE GMINNYM}

Streszczenie. W pracy scharakteryzowano warunki środowiskowe dla wybranej lokalizacji składowiska na terenie Starego Sącza, przeznaczonego do deponowania odpadów obojętnych pochodzących z zakładanej instalacji do segregacji wtórnej odpadów. Na podstawie produktywności wybranych odpadów komunalnych określono parametry wskaźników nagromadzenia w ścisłym związku z wielkością przewidywanych do składowania odpadów. Składowe obiektu dobrano z uwzględnieniem wymogów rozporządzenia z dnia 30 kwietnia 2013 r. w sprawie składowisk odpadów (Dz.U. 2013 poz. 523) dla zastosowania rozwiązań służących ochronie środowiska wodno-gruntowego i powietrza atmosferycznego $\mathrm{w}$ jego otoczeniu, przed negatywnym oddziaływaniem odpadów. Praca zawiera również odniesienie do etapu końcowego związanego z zamknięciem składowiska przy założonym kierunku jego rekultywacji. Artykuł zakończono wnioskami, wskazującymi na ograniczoną możliwość usytuowania takiego obiektu na wybranym terenie ze względu na położenie w nieznacznym oddaleniu od rzeki Poprad i na terenie Głównego Zbiornika Wód Podziemnych. Celem pracy była próba doboru elementów składowych instalacji do unieszkodliwiania odpadów w miejscowości Stary Sącz przy uwzględnieniu lokalnych uwarunkowań środowiskowych.

Słowa kluczowe: odpady komunalne, składowisko odpadów, deponowanie 